\title{
KEDUDUKAN HUKUM PEMEGANG POLIS PERUSAHAAN ASURANSI PAILIT DI INDONESIA
}

\author{
Togar Manihuruk, Program Magister Hukum Universitas Lancang Kuning, \\ E-mail : tmanihuruk03@yahoo.com \\ Yeni Triana, Program Pascasarjana Universitas Lancang Kuning, \\ E-mail : yeni_hukum@yahoo.com \\ Hj. Hasnati, Program Pascasarjana Universitas Lancang Kuning, \\ E-mail : hasnati.unilak@yahoo.com
}

doi: https://doi.org/10.24843/KS.2020.v08.i11.p07

\begin{abstract}
ABSTRAK
Tujuan study ini untuk menganalisis kedudukan hukum pemegang polis perusahaan asuransi pailit, apakah sebagai kreditur preferen atau kreditur kongkuren menurut hukum kepailitan di Indonesia. Studi ini menggunakan metode penelitian hukum normatif dengan pendekatan konseptuan dan perundang-undangan. Hasil studi menunjukkan bahwa kedudukan hukum pemegang polis perusahaan asuransi pailit menurut hukum kepailitan di Indonesia adalah masuk kategori kreditur preferen.
\end{abstract}

Kata Kunci : Kepailitan, Perusahaan asuransi, Kreditr preferen

\begin{abstract}
The purpose of this study is to analyze the legal position of bankrupt insurance company policyholders, whether they are preferred creditors or non-secured creditors according to bankruptcy law in Indonesia. This study uses a normative legal research method with a conceptual approach and statute approach. The study result shows that the legal position of bankrupt insurance company policyholders according to the bankruptcy law in Indonesia is in the preferred creditor category.
\end{abstract}

Keywords : Bankruptcy, Insurance Company, Preferred Creditors

\section{Pendahuluan}

\section{Latar Belakang Masalah}

Dampak memburuknya perekonomian mengakibatkan semakin banyak usaha yang tidak dapat melanjutkan usahanya, termasuk tidak mampu memenuhi kewajibannya kepada krediturnya. Ketidakmampuan debitur untuk melaksanakan kewajiban kepada kreditur, memberi hak kepada kreditur untuk mengajukan permohonan pailit debitur tersebut melalui pengadilan. Begitu juga dengan perusahaan yang bergerak di dunia asuransi tidak menutup kemungkinan mengalami kepailitan. ${ }^{1}$

${ }^{1}$ Manik, Edwind. (2012). Cara Mudah Memahami Proses Kepailitan dan Penundaan Kewajiban Pembayaran Utang (Dilengkapi Dengan Studi Kasus Kepalitan), (Bandung: Mandar Maju ), 16-17. 
Defenisi asuransi atau pertanggungan dalam Kitab Undang-undang Hukum Dagang (KUHD) Pasal 246 diatur : "Asuransi atau pertanggungan adalah perjanjian, dengan mana seseorang penanggung mengikatkan diri kepada seorang tertanggung, dengan menerima premi, untuk memberikan penggantian kepadanya karena suatu kerugian, kerusakan atau kehilangan keuntungan yang dihadapinya yang mungkin akan dideritanya karena suatu peristiwa yang tak tentu." 2 Asuransi merupakan sarana finansial dalam tata kehidupan rumah tangga, baik dalam menghadapi resiko yang mendasar, seperti resiko kematian, atau dalam menghadapi resiko atas harta benda yang dimiliki. Perusahaan asuransi merupakan lembaga keuangan non-bank yang mempunyai peranan yang tidak jauh berbeda dari bank yaitu bergerak dalam bidang layanan jasa yang diberikan kepada masyarakat di masa yang akan datang. ${ }^{3}$

Sesuai konsepnya asuransi pada prinsipnya adalah peralihan resiko. Dalam hal ini ada peralihan resiko dari si pemegang polis atau nasabah kepada pihak perusahaan asuransi, dimana pemegang polis atau nasabah wajib membayar premi asuransi sesuai kesepakatan. Persoalannya bahwa pada umumnya jangka waktu perlindungan asuransi yang disepakati adalah dengan tenggang waktu yang relatif cukup lama . Kita tidak tahu juga apa yang akan terjadi terhadap perusahaan asuransi tersebut pada jangka waktu lima tahun, sepuluh tahun atau bahkan dua puluh tahun ke depan. Adalah merupakan keniscayaan bahwa karena disebabkan satu dan lain hal, suatu perusahaan asuransi di kemudian hari dapat dinyatakan pailit melalui proses peradilan. Putusan pengadilan yang menyatakan suatu perusahaan asuransi pailit akan sangat berdampak kepada seluruh nasabah perusahaan asuransi dimaksud. Uang para nasabah baik yang belum jatuh tempo maupun yang telah jatuh tempo saat perusahaan asuransi dimaksud dinyatakan pailit harus dilindungi oleh hukum.

Berikut ini adalah beberapa contoh perusahaan asuransi di Indonesia yang telah dinyatakan pailit berdasarkan putusan pengadilan dan sudah berkekuatan hukum tetap. Pengadilan Niaga Jakarta Pusat berdasarkan putusan No.17/Pailit/2001/PN.Jkt.Pst tertanggal 28 Mei 2001 lalu, telah memutus bahwa PT Asuransi Jiwa Namura Tata Life (Asuransi Namura) dinyatakan pailit, dan putusan ini telah berkekuatan hukum tetap. Dan selanjutnya adalah PT Asuransi Jiwa Bumi Asih Jaya yang bermasalah dan mengalami gagal bayar atas klaim asuransi dari para nasabah. Akibat gagal bayar tersebut atas gugatan permohonan pailit yang diajukan oleh Otoritas Jasa Keuangan terhadap PT Asuransi Jiwa Bumi Asih Jaya, Mahkamah Agung telah memutus bahwa PT Asuransi Jiwa Bumi Asih Jaya dinyatakan pailit, berdasarkan putusan Nomor 408 K/Pdt.Sus.Pailit/2015 yang telah berkekuatan hukum tetap. Setelah kedua perusahaan asuransi di atas dinyatakan pailit mengakibatkan banyaknya para pemegang polis dari kedua perusahaan asuransi ini yang nasibnya terkatung-katung tidak jelas bagaimana pengembalian dana mereka

\footnotetext{
${ }^{2}$ Kitab Undang-undang Hukum Dagang

${ }^{3}$ Syilvina dan Rachmawati, Titiek. "Analisis Kebangkrutan dengan menggunakan Model Altaman ZScore pada Perusahaan Asuransi yang Go publik di Bursa Efek Indonesia” Jurnal (periode tahun 2010-2013).
} 
yang sudah disetorkan dalam jangka waktu yang lama dan bahkan ada yang sudah puluhan tahun.

Kedudukan pemegang polis setelah suatu perusahaan asuransi dinyatakan pailit memang tidak jelas diatur dalam Undang-Undang Kepailitan. Sebagai kreditur, belum jelas apakah pemegang polis berkedudukan sebagai kreditur konkuren (biasa), kreditur didahulukan, ataukah kreditur separatis (istimewa). Hal ini mengingat kedudukan dan status kreditur akan berbanding lurus dengan perolehan yang mereka dapatkan pasca kepailitan suatu perusahaan asuransi.

Sebagai gambaran, kreditur konkuren (biasa) hanya akan mendapatkan sisa harta pailit setelah dikeluarkan untuk biaya-biaya yang harus didahulukan pengeluarannya setelah debitur pailit. Itu pun pembagiannya secara prorata. Sedangkan apabila kedudukannya sebagai kreditur yang didahulukan, kreditur tersebut akan mendapatkan pembagian terlebih dahulu.

Di sisi lain berdasarkan Pasal 1139 KUHPerdata telah ditentukan piutangpiutang mana saja yang termasuk piutang didahulukan pembayarannya. Kewajiban perusahaan asuransi terhadap pemegang polis ternyata tidak termasuk piutang yang harus didahulukan pembayarannya, sebagaimana diatur pada Pasal 1139 tersebut. Artinya, bila mengacu pada KUHPerdata, kedudukan pemegang polis adalah sebagai kreditur konkuren alias kreditur nomor urut paling terakhir.

Akan tetapi sebaliknya berdasarkan Penjelasan Pasal 20 ayat (2) UndangUndang Nomor 2 tahun 1992 tentang Usaha Perasuransian diatur bahwa dalam hal kepailitan, hak pemegang polis mempunyai kedudukan yang lebih tinggi dari pada hak-hak pihak lainnya, kecuali dalam hal kewajiban negara. Kemudian aturan ini dicabut berdasarkan Undang-Undang Nomor 40 Tahun 2014 tentang Perasuransian. Pada Undang-Undang Nomor 40 Tahun 2014 Pasal 52 ayat (1) diatur "Dalam hal perusahaan asuransi, perusahaan asuransi syariah, perusahaan reasuransi, atau perusahaan asuransi syariah dipailitkan atau dilikuidasi, hak Pemegang Polis, Tertangggung, atau Peserta atas pembagian harta kekayaannya mempunyai kedudukan yang lebih tinggi daripada hak pihak lainnya." 4

Adanya dua pijakan hukum sebagaimana diuraikan di atas, menjadikan kedudukan hukum pemegang polis asuransi dalam hal adanya kepailitan menjadi ambigu. Selanjutnya berdasarkan uraian di atas, maka isu sentral dalam penulisan tesis ini adalah kedudukan hukum pemegang polis sebagai kreditur. Penulis berharap karya tulis ini dapat menambah wawasan, khususnya bagi Penulis dan bagi masyarakat pada umumnya.

\section{Rumusan Masalah}

Bertolak dari isu sentral diatas, maka selanjutnya Penulis merumuskan rumusan masalah untuk dibahas secara lebih rinci pada bab pembahasan sebagai

\footnotetext{
${ }^{4}$ Undang-Undang Nomor 40 Tahun 2014 tentang Perasuransian.
} 
berikut : Bagaimanakah kedudukan hukum pemegang polis perusahaan asuransi pailit di Indonesia?

\section{Tujuan Penulisan}

Adapun tujuan penulisan penelitian ini adalah untuk menganalisis kedudukan hukum pemegang polis perusahaan asuransi pailit di Indonesia.

\section{Metode Penelitian}

Adapun sistematika metode penelitian yang Penulis pilih dalam penulisan karya tulis ini adalah sebagaimana diuraikan berikut ini :

a. Jenis Penelitian

Menurut Peter Mahmud Marzuki, 5 penelitian hukum (legal research) merupakan suatu proses ilmiah untuk mencari pemecahan atas isu hukum yang muncul dengan tujuan untuk memberikan preskripsi mengenai apa yang seyogianya atas isu hukum yang muncul tersebut. Penelitian hukum dilakukan untuk menghasilkan argumentasi, teori atau konsep baru sebagai preskripsi dalam menyelesaikan masalah yang dihadapi. Oleh karena itu pilihan terhadap satu atau beberapa metode penelitian terkait erat dengan perumusan masalah, objek yang diteliti serta tradisi keilmuan itu sendiri. ${ }^{6}$

Mengingat bahwa penelitian ini merupakan penelitian untuk menganalisis kedudukan hukum pemegang polis perusahaan asuransi pailit di Indonesia, dan dikaitkan dengan substansi dari pada penelitian ini, maka penelitian ini merupakan penelitian hukum normatif atau penelitian doktrinal.

\section{b. Pendekatan Penelitian}

Dalam penelitian hukum diperlukan metode pendekatan yang dimaksudkan untuk mendapatkan informasi dari berbagai aspek mengenai isu hukum yang sedang dicoba untuk dicari jawabnya. ${ }^{7}$ Dalam penulisan ini pendekatan yang digunakan untuk menganalisis permasalahan dalam penelitian ini meliputi :

- Pendekata konseptual (conceptual approach);

- Pendekatan undang-undang (statute approach);

Pendekatan konseptual (conceptual approach) beranjak dari pendapat ahli (doktrin) yang terkait dengan prinsip-prinsip umum kepailitan, asas hukum-asas

\footnotetext{
${ }^{5}$ Marzuki, Peter Mahmud. (2003). Penelitian Hukum, Volume 16, No. 2, Maret 2001, (Jakarta : Prenada Media), 103.

${ }^{6}$ Philipus, M. Hadjon. (1994). Pengkajian Ilmu Hukum Dogmatik (Normatif), (Surabaya : Fakultas Hukum Universitas Airlangga), 32.

${ }^{7}$ Ibid. 93
} 
hukum. Sedangkan untuk pendekatan undang-undang (statute approach), terutama difokuskan pada ketentuan hukum perdata yang berlaku di Indonesia, UndangUndang Nomor 37 Tahun 2004 tentang Kepailitan dan Penundaan Kewajiban Pembayaran Utang, Undang-Undang No.40 Tahun 2007 Tentang Perseroan Terbatas, Undang-Undang No.21 Tahun 2011 Tentang Otoritas Jasa Keuangan, UndangUndang Nomor 40 tahun 2014 tentang Perasuransian.

Berdasarkan jenis dan pendekatan penelitian di atas, penulis akan menganalisis kedudukan hukum pemegang polis perusahaan asuransi pailit di Indonesia.

\section{c. Sumber Data}

Dalam penelitian ini, penulis mengolah data berdasarkan data sekunder. Data sekunder adalah data yang diperoleh atau didapatkan melalui penelitian kepustakaan (library research) atau studi dokumentasi. Penelitian kepustakaan dilakukan untuk mendapatkan data yang berupa norma-norma hukum, teori-teori hukum, doktrin hukum, asas-asas hukum, dan pemikiran konseptual serta penelitian pendahulu yang berkaitan dengan objek kajian penelitian ini. ${ }^{8}$

Berikut adalah bahan yang digunakan dalam pembahasan permasalahan hukum dalam karya tulis ini:

- Bahan hukum primer; Bahan Hukum Primer adalah bahan-bahan yang digunakan berdasarkan suatu aturan, undang-undang, hukum tertulis, dan segala bentuk batasan tertulis yang telah disepakati. Dalam hal ini yang termasuk bahan hukum primer adalah :

- Undang-Undang Nomor 37 Tahun 2004 tentang Kepailitan dan Penundaan Kewajiban Pembayaran Utang;

- Undang - Undang No.40 Tahun 2007 Tentang Perseroan Terbatas;

- Undang - Undang No.21 Tahun 2011 Tentang Otoritas Jasa Keuangan;

- Undang-Undang Nomor 40 tahun 2014 tentang Perasuransian

- Kitab Undang-Undang Hukum Perdata

- Kitab Undang-Undang Hukum Dagang;

- Bahan hukum sekunder; Bahan Hukum Sekunder yaitu bahan-bahan yang erat hubungannya dengan Bahan Hukum Primer dan dapat membantu menganalisa dan memahami Bahan Hukum Primer, yang berupa buku-buku dan artikel maupun jurnal hukum yang memuat penjelasan mengenai ; Teori-teori tujuan

\footnotetext{
${ }^{8}$ Ngani, Nico. (2012). Metodelogi Penelitian dan Penulisan Hukum, (Yogyakarta: Pustaka Yustisia),
} 78-79. 
hukum, asas hukum-asas hukum, Hukum perjanjian, Hukum Asuransi, Hukum Kepailitan, Hukum Perusahaan, literatur tentang kewenangan Otoritas Jasa Keuangan dalam perkara kepailitan perusahaan asuransi atau perusahaan reasuransi, literatur mengenai teori kepastian hukum, asas-asas hukum, teori perjanjian atau perikatan dan lain sebagainya.

- Bahan Hukum Tersier; Bahan Hukum Tersier merupakan bahan untuk melengkapi dan memberi penjelasan lebih lanjut. Bahan Hukum Tersier dalam penulisan karya tulis ini adalah Kamus Hukum, Kamus Besar Bahasa Indonesia, ataupun sumber-sumber dari internet. ${ }^{9}$

\section{Hasil dan Pembahasan}

Akibat hukum secara umum yang terjadi yang disebabkan oleh putusan pailit atas sebuah perusahaan asuransi adalah bahwa terhadap harta debitur tersebut akan dilakukan sitaan umum dan selanjutnya boedel harta perusahaan asuransi pailit tersebut menjadi jaminan pembayaran hutang-hutang perusahaan asuransi pailit kepada semua krediturnya.

Selanjutnya langkah pertama yang harus diselesaikan dalam hal pembagian harta pailit adalah penentuan status atau kedudukan para kreditur. Kreditur mana saja yang digolongkan sebagai sebagai kreditur konkuren (biasa), kreditur didahulukan (kreditur preferen), dan yang menjadi kreditur separatis (istimewa). Hal ini mengingat kedudukan dan status kreditur akan berbanding lurus dengan perolehan yang mereka dapatkan pasca kepailitan suatu perusahaan asuransi. Sebagai gambaran, kreditur konkuren (biasa) hanya akan mendapatkan sisa harta pailit setelah dikeluarkan untuk biaya-biaya yang harus didahulukan pengeluarannya setelah debitur pailit. Itu pun pembagiannya secara prorata. Sedangkan apabila kedudukannya sebagai kreditur yang didahulukan (kreditur preferen atau seoaratis, maka kreditur tersebut akan mendapatkan pembagian terlebih dahulu.

Defenisi asuransi atau pertanggungan dalam Kitab Undang-undang Hukum Dagang (KUHD) Pasal 246 diatur : "Asuransi atau pertanggungan adalah perjanjian, dengan mana seseorang penanggung mengikatkan diri kepada seorang tertanggung, dengan menerima premi, untuk memberikan penggantian kepadanya karena suatu kerugian, kerusakan atau kehilangan keuntungan yang dihadapinya yang mungkin akan dideritanya karena suatu peristiwa yang tak tentu."10

Berdasarkan Pasal 1139 KUHPerdata telah ditentukan piutang-piutang mana saja yang termasuk piutang didahulukan pembayarannya. Kewajiban perusahaan asuransi terhadap pemegang polis ternyata tidak termasuk piutang yang harus

\footnotetext{
${ }^{9}$ Soekarto, Soerjono dan Manudji, Sri. (2011). Penelitian Hukum Normatif, (Jakarta : PT Raja Grafindo Persada), 13-14.

${ }^{10}$ Kitab Undang-undang Hukum Dagang
} 
didahulukan pembayarannya, sebagaimana diatur pada Pasal 1139 tersebut. Artinya, bila mengacu pada KUHPerdata, kedudukan pemegang polis adalah sebagai kreditur konkuren alias kreditur nomor urut paling terakhir. Dan faktanya juga berdasarkan Undang-Undang Nomor 37 Tahun 2004 tentang Kepailitan dan Penundaan Kewajiban Pembayaran Utang ternyata kedudukan pemegang polis setelah suatu perusahaan asuransi dinyatakan pailit memang tidak jelas diatur.

Akan tetapi berdasarkan Undang-Undang Nomor 40 Tahun 2014 tentang Perasuransian pada Pasal 52 ayat (1) diatur : "Dalam hal perusahaan asuransi, perusahaan asuransi syariah, perusahaan reasuransi, atau perusahaan asuransi syariah dipailitkan atau dilikuidasi, hak Pemegang Polis, Tertangggung, atau Peserta atas pembagian harta kekayaannya mempunyai kedudukan yang lebih tinggi daripada hak pihak lainnya."11

Dengan demikian berdasarkan uraian di atas, maka terkait status atau kedudukan hukum pemegang polis perusahaan asuransi pailit terdapat antinomi hukum, atau pertentangan antara dua ketentuan peraturan perundang-undangan yang berbeda dan mengatur hal yang sama. Dalam hal ini praktis terdapat 2 (dua) peraturan perundang-undangan yang tumpang tindih dan saling berbenturan, yang mengatur substansi yang sama (overlapping).

Dalam hal terdapatnya antinomi hukum atau pertentangan hukum yang demikian, maka asas-asas hukum harus lebih diutamakan dari pada aturan atau ketentuan-ketentuan yang tertulis dalam undang-undang, dan inilah yang disebut dengan supremasi asas-asas hukum atas ketentuan perundang-undangan/hukum positif atau kembali ke asas hukum.

Berdasarkan asas hukum lex specialis derogat legi generalis, maka ketentuan peraturan perundang-undangan yang mengatur substansi hukum lebih khusus (specialis) mengesampingkan peraturan perundang-undangan yang memuat substansi hukum yang bersifat umum (generalis). Dengan kata lain jika terdapat 2 (dua) atau lebih undang-undang yang tumpang tindih yang mengatur substansi yang sama (overlapping), maka dari sudut pandang ilmu hukum harus diselesaikan dengan kembali dan merujuk kepada asas-asas hukum yang berlaku, yaitu : lex specialis derogat legi generalis.

Kitab Undang-Undang Hukum Perdata yang kita gunakan saat ini adalah merupakan peninggalan kolonial Belanda. Sehingga dalam hal ini maka ketentuan hukum dalam Kitab Undang-Undang Hukum Perdata tersebut, yang mengatur tentang asuransi adalah merupakan peraturan perundang-undangan yang bersifat umum (generalis).

Akan tetapi sebaliknya berdasarkan Undang-Undang Nomor 40 Tahun 2014 Pasal 52 ayat (1) diatur "Dalam hal perusahaan asuransi, perusahaan asuransi syariah, perusahaan reasuransi, atau perusahaan asuransi syariah dipailitkan atau

\footnotetext{
${ }^{11}$ Undang-Undang Nomor 40 Tahun 2014 tentang Perasuransian.
} 
dilikuidasi, hak Pemegang Polis, Tertangggung, atau Peserta atas pembagian harta kekayaannya mempunyai kedudukan yang lebih tinggi daripada hak pihak lainnya."

Undang-Undang Nomor 40 Tahun 2014 tentang Perasuransian adalah secara khusus diterbitkan mengatur ketentuan hukum terkait perasuransian, dengan demikian maka dapat disimpulkan bahwa Undang-Undang Nomor 40 Tahun 2014 tentang Perasuransian adalah merupakan hukum yang lex specialis terkait dengan perasuransian. Dengan demikian berdasarkan uraian di atas maka kedudukan hukum pemegang polis perusahaan asuransi yang pailit di Indonesia dikategorikan sebagai kreditur yang didahukukan atau kreditur preferen.

\section{Kesimpulan}

Berdasarkan asas hukum lex specialis derogat legi generalis, maka ketentuan hukum yang berlaku terkait status atau kedudukan hukum pemegang polis adalah ketentuan sebagaimana diatur berdasarkan Undang-Undang Nomor 40 Tahun 2014 Pasal 52 ayat (1) diatur "Dalam hal perusahaan asuransi, perusahaan asuransi syariah, perusahaan reasuransi, atau perusahaan asuransi syariah dipailitkan atau dilikuidasi, hak Pemegang Polis, Tertangggung, atau Peserta atas pembagian harta kekayaannya mempunyai kedudukan yang lebih tinggi daripada hak pihak lainnya.". Dengan demikian, maka kedudukan hukum pemegang polis perusahaan asuransi yang pailit di Indonesia dikategorikan sebagai kreditur yang didahukukan atau kreditur preferen. 


\section{Daftar Pustaka}

\section{Buku}

Agus. (2015). Pengantar Ilmu Hukum, Pengertian dan Perkembangannya di Indonesia, Malang : Setara Press

Bambang Sunggono, (2016). Metodologi Penelitian Hukum, Cetakan ke-16, Depok : Rajawali Pers

Chaedar Alwasilah. (2002). Pokoknya kualitatif : Dasar-dasar Merancang dan Melakukan Penelitian Kualitatif, Jakarta: Pusataka Jaya

Edwind Manik. (2012). Cara Mudah Memahami Proses Kepailitan dan Penundaan Kewajiban Pembayaran Utang (Dilengkapi Dengan Studi Kasus Kepalitan), Bandung: Mandar Maju

H. Man S. Sastrawidjaja, (2010). Hukum Kepailitan dan Penundaan Kewajiban Pembayaran Utang, Bandung : PT. Alumni

H. Salim HS, Erlies Septiana Nurbani. (2017). Penerapan Teori Hukum Pada Penelitian Disertasi dan Tesis, Buku Ketiga, Cetakan ke-2, Depok : Rajawali Pers

Mulhadi. (2017). Dasar-Dasar Hukum Asuransi, Depok : Rajawali Pers

Soerjono Soekarto dan Sri Manudji. (2011). Penelitian Hukum Normatif, Jakarta : PT Raja Grafindo Persada

Subadi. (2010). Penguasaan dan Penggunaan Tanah Kawasan Hutan, Jakarta : Prestasi Pustaka

Susanti Adi Nugroho. (2018). Hukum Kepailitan di Indonesia, Dalam Teori dan Praktek Serta Penerapan Hukumnya, Jakarta : Prenadamedia Group

Suteki, Galang Taufani. (2018). Metodologi Penelitian Hukum (Filsafat, Teori dan Praktik), Cetakan ke-1, Depok : PT Raja Grafindo Persada

\section{Jurnal}

Rachmawati, T. (2016). Analisis Kebangkrutan Dengan Menggunakan Model Altman ZScore Pada Perusahaan Asuransi Yang Go Public Di Bursa Efek Indonesia (Periode Tahun 2010-2013). JEB17: Jurnal Ekonomi dan Bisnis, 1(01). 61-74.

Wantu, F. M. (2007). Antinomi Dalam Penegakan Hukum Oleh Hakim. Mimbar Hukum-

Fakultas Hukum Universitas Gadjah Mada, 19(3). 335-485.

\section{Peraturan Perundang-undangan}

Undang-Undang Nomor 37 Tahun 2004 tentang Kepailitan dan Penundaan Kewajiban Pembayaran Utang

Kitab Undang-Undang Hukum Perdata

Undang-Undang Nomor 40 tahun 2014 tentang Perasuransian

Undang-Undang Nomor 21 tahun 2011 tentang Otoritas Jasa Keuangan

\section{Putusan Pengadilan}

Putusan Mahlamah Agung Republik Indonesia Nomor 408 K/Pdt.Sus.Pailit/2015 dalam perkara kepailitan antara Otoritas Jasa Keuangan melawan PT Asuransi Bumi Asih Jaya.

\section{Skripsi, Tesis \& Disertasi}

Ismadani Roflul Ulya. (2015). “Perlindungan Hukum Nasabah Pasca Pencabutan Ijin Usaha Perusahaan Asuransi Jiwa Bumi Asih Jaya (BAJ) oleh Otoritas Jasa Keuangan (OJK)", Skripsi Prodi Ilmu Hukum, Fakultas Syariah dan Hukum Universitas Islam Negeri Syarif Hidayatullah, Jakarta. 
M. Alpi Syahrin. (2011). “Kewenangan Menteri Keuangan Dalam Pengajuan Permohonan Pailit Terhadap Perusahaan Asuransi (Study Yuridis Undang-Undang Nomor 37 tahun 2004 Tentang Kepailitan dan Penundaan Kewajiban Pembayaran Utang)", Skripsi Program Studi Ilmu Hukum, Fakultas Syariah dan Hukum Universitas Islam Negeri Sultan Syarif Kasim, Riau.

Tri Minati. (2017). Analisis Yuridis Terhadap Permohonan Pailit Pada PT Asuransi Bumi Asih Jaya oleh OJK", Skripsi Program Studi Ilmu Hukum, Fakultas Syariah dan Hukum Universitas Islam Negeri Sunan Kalijaga, Yogyakarta.

\section{Website}

Leo. (2002). Kepailitan Perusahaan AsuransiAdilnya, Pemegang Polis Jadi Kreditur Didahulukan. https://www.hukumonline.com/berita/baca/hol6372/font-size1colorff0000bkepailitan-perusahaan-asuransibfontbradilnya-pemegang-polis-jadikreditur-didahulukan 